\title{
Public Sector Sustainability in the Balanced Scorecard - A Portuguese City Council Case
}

\author{
Inês Pereira, and Helena Costa Oliveira* \\ ISCAP, Polytechnic of Porto, Rua Jaime Lopes Amorim, s/n 4465-004 S., Mamede de Infesta, \\ Portugal
}

\begin{abstract}
Increasingly, sustainability has been integrated in public organizations, particularly by regional authorities. The Balanced Scorecard (BSC), as a tool for assessing and measuring the performance of organizations enables the integration of sustainability (in its environmental, social and economic issues) in a Sustainability Balanced Scorecard (SBSC). The purpose of this study is to design a SBSC for a Portuguese city council that assists a population of 24 thousand inhabitants. In this sense, it aims to structure the BSC's perspectives in the city council; interrelate sustainability issues in a SBSC, and; articulate the several perspectives on a strategic map. The present case resorts on a questionnaire sent to the city council president and document analysis. We conclude that the sustainability and the traditional structure of the BSC adapt to public organization. The study contributes to the development of sustainability in the public sector, presenting sustainability in an integrated and systemic manner, aligned with the several organizational responsibilities.
\end{abstract}

\section{Introduction}

The performance of organizations must improve in the three dimensions of sustainability environmental, social and economic - to achieve sustainable development [1]. It is important to control, understand and assess the performance of the organization follow up the implementation of sustainability, and monitor the relationship with the surrounding society. For Kaplan \& Norton [2] the Balanced Scorecard (BSC) is a management system focused on four perspectives structured in objectives to achieve the strategy of the organization. The BSC, properly adapted, allows the integration of sustainability in public management, and consequently, the emergence of the Sustainability Balanced Scorecard, (SBSC).

The public sector has significant influence in the daily lives of citizens, since it is a provider of several services and smooth essential to the good functioning of the community. Public management is of great importance for the population as it defines the path to the municipality to grow and develop. Public management is responsible for urban and economic development, so the mission and all procedures of a city council must be interconnected with such responsibility [3].

\footnotetext{
* Corresponding author: helena@iscap.ipp.pt
} 
Sustainability must be adopted as a necessary and indisputable guideline to conserve a more natural capital for future generations. Therefore, all the mechanisms of its implementation must be requested, concentrating all spheres of the public power to achieve this goal. The sustainability requirements involve cooperation between States, between the state and citizens (or civil society groups) in the promotion of public policies. It also involves the duty to adopt public and private behaviours focused on this goal to promote acceptance of conducts committed to the well-being of future generations. Sustainability allows institutions to involve social, economic and environmental issues in the strategy and in the management [4].

The BSC is a starting point to incorporate environmental and social issues into the institution's management system. The BSC supports sustainability management, overcoming gaps in conventional management systems and including the three pillars of sustainability in a unique and comprehensive strategic management tool [5].

The BSC is a tool for assessing and measuring the performance of organizations and to support management control. The authors [2] defined the BSC as a set of financial measures (reflecting the results of past actions) complemented by operational measures on customer satisfaction, internal processes, innovation and improvement of the organization (the drivers of future financial performance) showing managers a quick and wide view of the business [2]. Thus, the BSC identifies the objectives of four perspectives (financial, customers, internal processes and learning and growth) linked in a defined cause and effect relationship systemized in a strategic map.

The SBSC derives from the traditional BSC, with an adapted structure and content to integrate the three pillars of sustainability [6]. The broader structure of BSC provides to SBSC a methodology to bridge the gap between the strategic and operational level of the institutions [4]. The SBSC provides initial guidance for managers to make decisions about integrating environmental and social objectives into the organization's performance management system [7].

Since the BSC helps in the identification and management of simultaneous improvements in environmental, social and financial business objectives, a sustainability BSC fulfils the main requirement of sustainability for a permanent improvement of business performance concerning such objectives [5].

Regardless of some studies of the application of the SBSC in fields such as banks [8], airports [9], tourism [10], industry [11], agriculture [12] among others, as far as we know there is no study on the design of the SBSC for the public sector.

\section{Method}

We present a qualitative case study conducted in 2020. The study concerns features of reality that cannot be quantified, focusing on understanding and explaining the dynamics of social relationships [13].

The purpose of the paper is to design a SBSC for a city council in the north region of Portugal that assists a population of 24 thousand inhabitants. In this sense, the following research questions were identified: how should we structure the BSC perspectives for the city council?, how should we link sustainability issues in a BSC? and how should we articulate the various perspectives of the SBSC to the city council?

The study is based on document analysis, diverse information available on the city council website, and in a questionnaire sent to the president of the city council. Throughout the process, permanent contact with the city council was maintained through emails and phone calls. They had the purpose of validating the information, clarifying doubts and obtaining new information. The design of the SBSC was sent to the president of the institution to be validated. 
The sustainability pillars can be incorporated into a BSC by three different possibilities: integration of environmental and social issues in the four perspectives of the traditional BSC, through the creation of a new perspective, or by creating an isolated SBSC.

We followed the second option creating a new perspective in the BSC (the sustainability perspective). This is the strongest approach for institutions that want to make sustainability the key factor [14]. The need to create a new perspective arises when the strategically relevant issues of sustainability, outside the market system, can affect the performance of the institution in the four traditional perspectives of the BSC [5]. This option, despite improving the importance of sustainability for the organization, is more easily found in companies that have greater exposure to sustainability issues [14]. Epstein \& Wisner [1] present several reasons for companies to create a new perspective of sustainability: social and environmental responsibility is nowadays essential for the organizational strategy and not only as a means to improve operational efficiency; the creation of a fifth perspective leads managers and employees to focus on environmental and social issues and thus becomes a central corporate value; it is decisive when a company has very relevant social and environmental problems and wants to highlight its relevance; in case of excessive allocation of resources for social and environmental responsibility where the company intends to highlight the link between the resources and the company's strategy.

We started with the design of the strategy translation structure in operational terms. The strategic objectives for the traditional perspectives of the BSC are defined such as the fifth sustainability perspective to observe social and environmental issues.

Based on the city council organization chart the perspectives were identified. A link was made between the perspectives and the organization's divisions. The indicators were derived from the information identified in the documental analysis and validated by the president of the institution. We then proceeded to build the strategic map of the city council with the respective relationships between the five perspectives of the SBSC.

\section{Results and discussion}

The design of the SBSC follows the three steps proposed by Figge et al. [5]. Thus, the chosen strategic business unit was the entire city council (1). We identified the environmental and social exposure through the information collected in the Forecast Document (2019) (that included the Report of Activities, the Budget and the Major Plan Options). Thus, all environmental and social interventions developed and planned by the city council departments were selected (2). Finally, the social and environmental issues were determined through the information provided by the president interview, the Forecast Document (2019), information available on the website and through the two previous phases ((1) and (2)). Such issues are very relevant because the environment and social interests are related to the city council interests (3). Therefore, sustainability issues are strategic for the organization.

We formulate the perspectives of the BSC and add the sustainability perspective. Afterwards, the objectives, indicators and initiatives of each perspective were identified.

Based on the city council chart, we start linking the five perspectives with the organization's divisions. The financial perspective is related to the financial management division and the economic development division. The learning and growth perspective encompasses the general administration division and human resources. The internal processes perspective includes the municipal works and direct administration division; the urban planning and management division; the archives division; the library, the education division and the sport; leisure, tourism and culture division. The sustainability perspective covers the division of the environment and human services and economic development 
division (social welfare and housing). The citizen's perspective brings together all internal processes to obtain the satisfaction of the residents.

In the perspective of the citizens the following objectives were identified: satisfaction of the citizens and bring citizens closer to municipal services.

The objectives defined for the internal processes perspective were the following: to attraction of national and international tourists; creation of a learning space; provision of a cultural offer that reflects the identity of the municipality; promote and advertising of the action of the municipality in the field of sports. The objectives identified from the learning and growth perspective were: qualification of public services and employee satisfaction. The objectives identified from the financial perspective were as follows: debt reduction and promotion of a favourable economic environment to investment and growth.

The objectives identified from the sustainability perspective were the following: promotion of the quality of living of the population, increment of environmental values and adoption of safeguarding practices, to act on the social vulnerability of the most fragile population strata, to overcome social problems and the inclusion of citizens, to guarantee a successful school, foster local entrepreneurship, prevent collective risks and, finally, the improve existing roads and create new ones. Table 1 synthetizes the objective, initiatives and indicators of the city council sustainability perspective.

Table 1. Operational strategy of the sustainability perspective

\begin{tabular}{|c|c|c|}
\hline Objectives & Initiatives & Indicator \\
\hline $\begin{array}{l}\text { Promotion of the quality of } \\
\text { living of the population. }\end{array}$ & $\begin{array}{l}\text { Adoption of environmental } \\
\text { education policies and } \\
\text { environmental awareness } \\
\text { actions. }\end{array}$ & $\begin{array}{l}\text { Number of awareness } \\
\text { actions. }\end{array}$ \\
\hline $\begin{array}{l}\text { Increment of environmental } \\
\text { values and adoption of } \\
\text { safeguarding practices. }\end{array}$ & $\begin{array}{l}\text { Maintenance and preservation } \\
\text { of green spaces. }\end{array}$ & $\begin{array}{l}\text { Number of policies } \\
\text { adopted. }\end{array}$ \\
\hline $\begin{array}{l}\text { Act on the social } \\
\text { vulnerability of the most } \\
\text { fragile population strata. }\end{array}$ & $\begin{array}{l}\text { Intervention actions with the } \\
\text { elderly and the disabled } \\
\text { population. }\end{array}$ & $\begin{array}{l}\text { Number of } \\
\text { intervention actions. }\end{array}$ \\
\hline $\begin{array}{l}\text { Overcome social problems } \\
\text { and the inclusion of citizens. }\end{array}$ & Creation of social housing. & $\begin{array}{l}\text { Number of houses } \\
\text { created. }\end{array}$ \\
\hline $\begin{array}{l}\text { Guarantee a } \text { successful } \\
\text { school. }\end{array}$ & $\begin{array}{l}\text { Creation of integrated and } \\
\text { innovative plans to combat } \\
\text { school failure. }\end{array}$ & $\begin{array}{l}\text { Budget for schools } \\
\text { and pedagogical } \\
\text { activities by the } \\
\text { school. }\end{array}$ \\
\hline Foster local entrepreneurship & $\begin{array}{l}\text { Job creation. Support of } \\
\text { structures to defend interests } \\
\text { and opinions. }\end{array}$ & $\begin{array}{ll}\text { Jobs } & \text { created. } \\
\text { Investment } & \\
\text { incentives. } & \end{array}$ \\
\hline Prevent collective risks. & $\begin{array}{l}\text { Conducting awareness- } \\
\text { raising actions and improving } \\
\text { forest paths. }\end{array}$ & $\begin{array}{l}\text { Number of actions } \\
\text { taken towards forest } \\
\text { preservation. }\end{array}$ \\
\hline $\begin{array}{l}\text { Improve existing roads and } \\
\text { create new ones. }\end{array}$ & Execution of public works. & $\begin{array}{l}\text { Amount of funds for } \\
\text { public works. }\end{array}$ \\
\hline
\end{tabular}

Based on the previous design of the city council SBSC, the following strategic map was designed. 


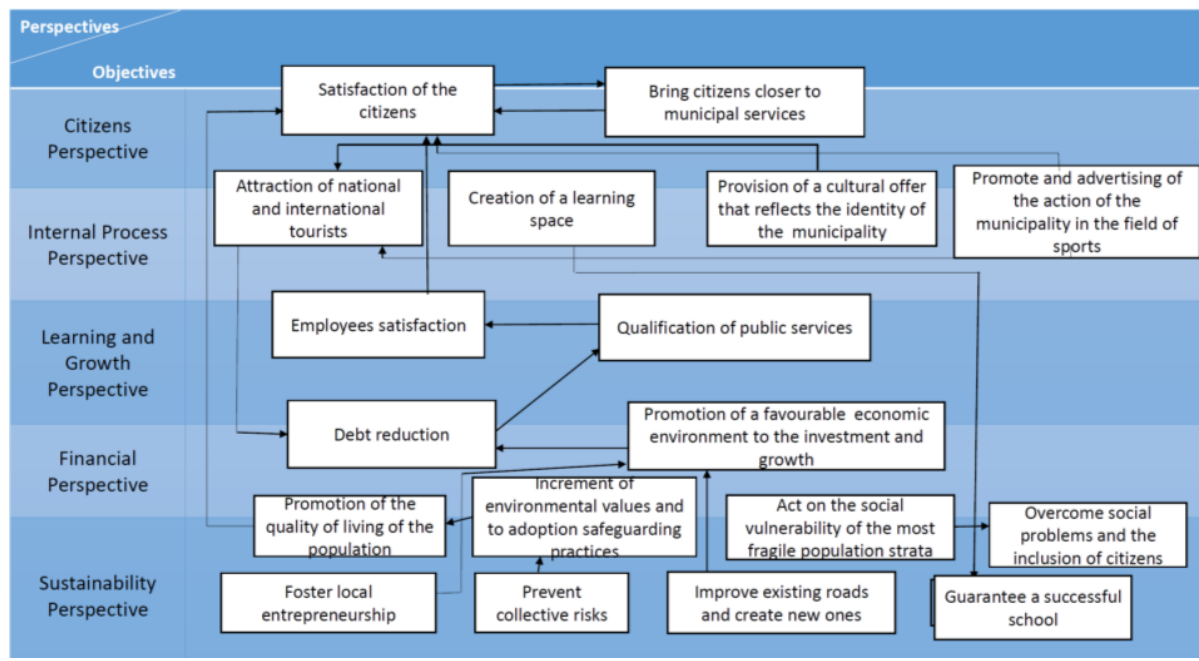

Fig. 1. Strategic map of the city council

The strategic map reflects relationships and the effect between the objectives of the several perspectives. It allows us to see the organization as a system with a well-defined guiding plan. We found that sustainability linked to the organization's management is feasible based on the identification of strategic relevance. The sustainability issues are directed linked to the social and environmental well-being of the city council, so it is a stable city council, of reference, and attractive to the population. Sustainable success will be achieved with the alignment of employees and internal processes with the overall satisfaction of the municipality.

\section{Conclusions}

The purpose of this study was to design a SBSC to a public organization. The BSC perspectives were identified, sustainability issues were acknowledged and adapted to the BSC philosophy. The SBSC perspectives were linked to a systemic strategic map.

The organization's mission and vision are concerned with the involvement of citizens in the creation of a sustainable municipality. For the city council, the main perspective is the citizens' one. The increase in the quality of living of the population and the satisfaction and integration of the citizens result from an aligned work that begins with processes of learning and growth and of social, environmental and economic sustainability. The implementation of the SBSC in a public organization is feasible, when properly adapted to the specific features of the organization.

This paper contributes to studies of sustainable development in public organizations. The design of the SBSC allows us to see the organization as an integrated system and to understand the mutual influences of the several objectives. Sustainable success is achieved by an organizational alignment. We suggest for future research the study of the difficulties of implementing the SBSC in public organizations.

\section{References}

1. M. J. Epstein, P. S. Wisner, Environmental Quality Management, 11 (2001)

2. R. Kaplan, D. Norton, Harvard Business Review, 70 (1992)

3. C. Adams, S. Muir, Z. Hoque, Sustainability Accounting, Management and Policy 
Journal, 5 (2014)

4. Z. T. Kalender, O. Vayvay, Procedia Social and Behavioral Sciences, 235 (2016)

5. F. Figge, T. Hahn, S. Schaltegger, M. Wagner, Business Strategy Environment, 11 (2002)

6. T. Bieker, Int. Summer Acad. Technol. Stud. - Corp. Sustain., 1-17 (2003)

7. E. G. Hansen, S. Schaltegger, Journal of Business Ethics, 133 (2016)

8. G. Yılmaz, M. Nuri İne, International Journal of Business and Social Science, 4 (2018)

9. M.-T. Lu, C.-C. Hus, J. Liou, H.-W. Lo, Journal of Air Transport Management, 71 (2018)

10. I. Giannoukou, C. C. Beneki, International Journal of Global Environmental Issues, 17 (2018)

11. R. Nurcahyo, S. Pustiwari, D. S. Gabriel, International Journal of Engineering \& Technology, 7 (2018)

12. L. Araújo, H. C. Oliveira, L. Gomes, E3S Web Conf., 159 (2020)

13. R. Yin, Thousand Oaks: Sage Publications (1994)

14. J. B. Butler, S. C. Henderson, Manag. Account. Q. Winter, 12 (2011) 